\title{
Deinocerites cancer Theobald (Diptera: Culicidae) on Grassy Key and Long Key in the Florida Keys, USA
}

\author{
Lawrence J. Hribar ₹
}

‡ Florida Keys Mosquito Control District, Florida, United States of America

\begin{abstract}
\section{Background}

The Florida Keys Mosquito Control District has deployed dry ice-baited light traps to monitor mosquito populations throughout the Florida Keys starting in 1998. The crab hole mosquito, Deinocerites cancer Theobald (Diptera: Culicidae) is a common mosquito throughout the Florida Keys.
\end{abstract}

\section{New information}

This paper describes a data set compiled over almost 20 years of trapping on Grassy Key and Long Key, Florida.

\section{Keywords}

Diptera, Culicidae, seasonal abundance, Grassy Key, Long Key 


\section{Introduction}

The Florida Keys Mosquito Control District conducts adult mosquito surveillance by means of dry ice-baited light traps. Light traps have been used for nearly twenty years to monitor populations of adult mosquitoes. Trapping is done weekly except for interruptions due to storms, illness, or other unavoidable situations. Traps are provisioned with 2 pounds of dry ice and deployed in the late afternoon and retrieved the following morning. Traps are hung from the same tree limb each time except when trees have been uprooted due to storrms or human activity. Mosquitoes are taken to the laboratory, killed by freezing, and identified to species.

Deinocerites cancer Theobald is known as the "crabhole mosquito" mosquito due to its larval habitat, burrows of the land crab, Cardisoma guanhumi Latrielle. Adult female $D$. cancer take blood meals primarily from warm blooded animals, especially birds in the order Ciconiiformes (Tempelis and Galindo 1970). This species has been found infected with West Nile Virus (Hribar et al. 2003).

\section{General description}

Purpose: These data were collected in order to document the seasonal distribution of Deinocerites cancer in the Florida Keys.

\section{Sampling methods}

Study extent: Trapping of mosquitoes on Grassy Key began in the late summer of 1998 and continued until the present. Attempts were made to collect weekly although due to storms, illness, and vacation this was not always possible.

Sampling description: Battery powered light traps (American Biophysics Company, Clarke, John Hock) were baited with approximately two pounds of dry ice and hung from the same tree limb once per week for almost 20 years. Traps were deployed in the late afternoon and retreived the following morning. Trap catch was transported to the laboratory, frozen, and all mosquitoes separated, identified, and counted. Data were recorded in spreadsheets. Voucher specimens are retained in the mosquito collection of the Florida Keys Mosquito Control District.

\section{Geographic coverage}

Description: The islands of Grassy Key $\left(24^{\circ} 45^{\prime} 18.28^{\prime \prime} \mathrm{N}, 80^{\circ} 57^{\prime} 58.47^{\prime \prime} \mathrm{W}\right)$ and Long Key $\left(24^{\circ} 49^{\prime} 39.65^{\prime \prime} \mathrm{N}, 80^{\circ} 48^{\prime} 38.40^{\prime \prime} \mathrm{W}\right)$ in Monroe County, Florida, United States. 


\section{Usage rights}

Use license: Creative Commons Public Domain Waiver (CC-Zero)

\section{Data resources}

Data package title: Excel

Number of data sets: 1

Data set name: Deinocerites cancer

\begin{tabular}{|l|l|}
\hline $\begin{array}{l}\text { Column } \\
\text { label }\end{array}$ & Column description \\
\hline YEAR & The year in which a collection was made. \\
\hline DOY & The day of the year when a trap was deployed on (1-365 or 366 in leap years). \\
\hline GK & $\begin{array}{l}\text { The number of adult Deinocerites cancer collected in the trap on Grassy Key during that sampling } \\
\text { period. }\end{array}$ \\
\hline LK & $\begin{array}{l}\text { The number of adult Deinocerites cancer collected in the trap on Long Key during that sampling } \\
\text { period. }\end{array}$ \\
\hline
\end{tabular}

\section{Additional information}

The size of the dataset is $29 \mathrm{~KB}$. The file format is XML. Data are available in file Suppl. material 1.

\section{Acknowledgements}

I thank all biologists and techicians who assisted with data collection and specimen identification during the past twenty years.

\section{References}

- Hribar LJ, Vlach JJ, DeMay DJ, Stark LM, Stoner RL, Godsey MS, Burkhalter KL, Spoto MC, James SS, Smith JM, Fussell EM (2003) Mosquitoes infected with West Nile Virus in the Florida Keys, Monroe County, Florida, USA. Journal of Medical Entomology 40 (3): 361-363. https://doi.org/10.1603/0022-2585-40.3.361

- $\quad$ Tempelis CH, Galindo P (1970) Feeding habits of five species of Deinocerites mosquitoes collected in Panama. Journal of Medical Entomology 7 (2): 175-179. https:// doi.org/10.1093/jmedent/7.2.175 


\section{Supplementary material}

\section{Suppl. material 1: Deinocerites cancer doi}

Authors: L.J. Hribar

Data type: trap catch

Brief description: Twenty years collection data for Deinocerites cancer Theobald on Grassy Key and Long Key, Monroe County, Florida.

Download file $(29.07 \mathrm{~kb})$ 